\title{
Effect of sources and levels of potassium in cotton as influenced fractions of soil potassium under vertisols in Vidarbha region of Maharashtra
}

\author{
Y. B. KADAM, V. K. KHARCHE, V. S. BORKAR, N. M. KONDE AND V.V. GABHNE
}

Received : 22.09.2016; Revised : 15.10.2016; Accepted : 10.11.2016

\section{MEMBERS OF RESEARCH FORUM:}

Corresponding author :

Y. B. KADAM, Department of Soil Science and Agricultural Chemistry, Dr. Panjabrao Deshmukh Krishi Vidyapeeth, AKOLA (M.S.) INDIA Email: y.b.kadam1986@gmail.com

Co-authors :

V. K. KHARCHE, V. S. BORKAR, N. M. KONDE AND V.V. GABHNE,

Department of Soil Science and Agricultural Chemistry, Dr.

Panjabrao Deshmukh Krishi

Vidyapeeth, AKOLA (M.S.) INDIA

\section{Summary}

The present investigation was carried out in vertisols of Akola district of Maharashtra to ascertain the effect of potassium application on yield and quality of Bt cotton. This was carried out by conducting field experiments on research farm of Department of Soil Science and Agricultural Chemistry, Dr. Panjabrao Deshmukh Krishi Vidyapeeth, Akola and similarly on five farmer's fields in intensive cotton growing area of vertisols in Akola district during 2012-13 and 2013-14. The treatments comprised of various levels of potassium $(0,25,50 \mathrm{~kg}$ $\mathrm{K}_{2} \mathrm{O} \mathrm{ha}^{-1}$ ) applied through either MOP or SOP and additional foliar sprays of SOP @ 1.5 per cent at critical growth stages of cotton alongwith addition of equivalent quantity of sulphur through bensulf and control without potassium. The fractions of soil potassium were found to be increased alongwith increasing levels of potassium. The reduction in fractions of soil potassium during peak growth stages suggests that there was highest uptake of potassium during this stage and supplemental foliar application of potassium (SOP) had significant response at critical growth stages. The vertisols of present investigation categorized as low to medium in sulphur. Application of sulphur @ $18 \mathrm{~kg} \mathrm{ha}^{-1}$ through bensulf was also found equally beneficial as that of SOP for increasing yield. From the present investigation it can be concluded that the fractions of potassium in soil decreased at critical growth stages of cotton viz., flowering and boll development due to increasing uptake by cotton. The application of potassium @ $50 \mathrm{~kg} \mathrm{~K}_{2} \mathrm{O} \mathrm{ha}{ }^{-1}$ either through MOP or SOP irrespective of sources showed increase in soil potassium fractions and improvement in soil fertility.

Key words : Fractions of soil potassium, Nutrient mining, Soil fertility

How to cite this article : Kadam, Y. B. , Kharche, V. K., Borkar, V. S., Konde, N. M. and Gabhne, V.V. (2016). Effect of sources and levels of potassium in cotton as influenced fractions of soil potassium under vertisols in Vidarbha region of Maharashtra. Asian J. Soil Sci., 11 (2) : 246-257 : DOI : 10.15740/ HAS/AJSS/11.2/246-257. 